\title{
A bovine viral diarrhea virus type 1a strain in China: isolation, identification, and experimental infection in calves
}

Wei Wang ${ }^{1,2}$, Xinchuan Shi ${ }^{2}$, Qin Tong ${ }^{2}$, Yongwang $\mathrm{Wu}^{2}$, Ming Qi Xia ${ }^{2}, \mathrm{Ye} \mathrm{Ji}^{2}$, Wenzhi Xue ${ }^{3}$ and Hua Wu ${ }^{1 *}$

\begin{abstract}
Background: Bovine viral diarrhea virus (BVDV) is one of the most important pathogens in cattle. Previously, BVDV sub-genotypes of 1b, 1c, 1d, and $1 \mathrm{~m}$ were detected in China. However, isolation of BVDV type 1a from cattle has not been reported in China. In 2010, twenty nasal swabs and blood samples were collected from the cattle suspected BVDV infection in Henan province, China. A BVDV isolate was isolated using cell culture, and the pathogenesis of the virus isolate was studied.

Methods: Virus isolation was performed on MDBK cells. The virus identification was conducted by RT-PCR, neutralization test and immunofluorescence assay. In order to determine the genotype of the newly isolated virus, the $5^{\prime}$ un-translated region ( $\left.5^{\prime} U T R\right)$ of the virus isolate was cloned, sequenced and phylogenetically analyzed. To evaluate the virulence of the virus isolate, four BVDV sero-negative calves were intranasally inoculated with the virus suspension. Rectal temperatures and clinical signs were recorded daily. Blood samples were analyzed for changes in white blood cell counts, and tissue samples were taken for histopathology analysis.
\end{abstract}

Results: A new isolate of bovine viral diarrhea virus (BVDV), named HNO1, was isolated from the nasal swabs using MDBK cell culture. The HN01 strain caused cytopathic effect (CPE) in MDBK cell cultures after two passages. The virus specifically reacted to BVDV1-specific monoclonal antibody in an immunofluorescence assay. A fragment of $288 \mathrm{bp}$ of genome from this isolate was amplified by the RT-PCR. Phylogenetic analysis of $5^{\prime}$ UTR indicated that the virus was BVDV 1a. In the pathogenesis study, four calves experimentally infected with the BVDV strain developed depression, cough and other clinical signs. Calves showed high temperature over $40^{\circ} \mathrm{C}$, and white blood cell counts dropped more than $40 \%$.

Conclusions: A new subgenotype 1a strain of BVDV was firstly isolated from dairy cattle in China. The experimental infection showed that the virus was moderate pathogenic to cattle and can be used as a BVDV challenge virus to evaluate the efficacy of BVDV vaccines in the target animals.

Keywords: Bovine viral diarrhea virus, BVDV, Cattle, Phylogenetic analysis, Pathogenesis, China

\section{Background}

Bovine viral diarrhea virus (BVDV) is a great economically pathogen in cattle and other ruminants in the world [1-10]. The virus is associated with several clinical symptoms, including diarrhea, respiratory disease, congenital malformations, reproductive disorders and mucosal disease [9,11-14].

\footnotetext{
* Correspondence: wuhua@sinovetah.com

${ }^{1}$ Institute of Special Economic Animal and Plant Science, CAAS, No. 4899, Juye Street, 130122 Changchun, PR China

Full list of author information is available at the end of the article
}

BVDV belongs to the genus pestivirus with classical swine fever virus and border disease virus in the family Flaviviridae. The genome of the BVDV consists of a single positive-stranded RNA, which usually have a length of $12.3 \mathrm{~kb}$ [15]. Two biotypes of BVDV categorized as cytopathogenic or noncytopathogenic based on their activity in cell culture have been recognized in the past years [16,17]. Based on the basis of the nucleotide sequence of $5^{\prime}$-untranslated region ( $\left.5^{\prime} \mathrm{UTR}\right), \mathrm{N}^{\text {pro }}$ or E2 gene, BVDV strains can be divided into two different genotypes, BVDV1 and BVDV2 [18]. Each genotype can be 
further divided into different subgroups, and currently at least 11 genetic subgroups of BVDV1 and three genetic subgroups of BVDV2 are identified [3,6,18-24]. Recently, a new virus referred to as HoBi-like BVDV3 was identified in Europe, the virus can be divided into two sub-groups, Thai origin and Brazilian origin [25]. BVDV1 spreads worldwide in cattle population [22,23,26,27]. In the case of BVDV2 species, the highest occurrence is reported in the USA and Canada [25,28], partially in Japan [29-31], Indian [3], South America [19], and occasionally in some European countries [6,15,32-35].

Virulence is both important to understanding the mechanisms of pathology and selecting the challenge strains for evaluation of a vaccine. Variation in virulence among BVDV2 strains has been extensively reported [36-38], but much less information is available on variation in virulence among BVDV1 strains. To date, the strain NY-1 has been used as a challenge strain for evaluating efficacy of vaccine protection against BVDV1. While it is well characterized, the clinical presentation infected with NY-1 indicates it is more likely a low virulence strain [39]. So investigating an efficacious challenge virus to access the vaccine efficacy is very important.

To the present, many subgenotypes of BVDV1 have been isolated and detected in China [27,40,41]. Based on the phylogenetic tree, the clustering of BVDV1b and BVDV $1 \mathrm{~m}$ were the major prevalent subgenotypes in China $[27,41,42]$. However, BVDV subgenotype 1a was not isolated from cattle in China. Moreover, pathogenesis of above all strains was seldom reported.

In this study, one virus was isolated from nasal swabs of cattle using MDBK cell cultures, and identified as a BVDV isolate by the virus neutralization test, reverse transcriptase-polymerase chain reaction (RT-PCR) method and immunofluorescence assay. To investigate the genetic subgroup of the strain, the 5'UTR gene of the virus was sequenced and compared with other 13 reference BVDV strains by phylogenetic analysis. The pathogenesis of the virus was evaluated by intranasally inoculating to four susceptible calves to assess the potential endemic risk to the cattle herd in China.

\section{Results}

\section{Virus isolation}

A virus isolate was isolated from the nasal swab samples after two blind passages on MDBK cells. The MDBK cells inoculated with nasal swab samples developed obvious cytopathic effects (CPE) as cells appeared aggregated and formed net-like in the monolayers within 48 hours of incubation. The non-inoculated control cells did not show the CPE. Specific fluorescent staining showed the appearance in form of granules distribution all over the cytoplasm in the infected MDBK cells, when an indirect immunofluorescence test was conducted using BVDV1 type-specific monoclonal antibodies (E2/gp53 IgG2a Isotype, VMRD, USA). The control cells did not show any fluorescence (Figure 1).

In virus neutralization assay using BVDV anti-sera, results revealed that the inoculated MDBK cells did not show CPE after mix of the virus fluids with BVDV1 positive serum, but cells inoculated with virus fluid only developed CPE. These results indicate that the virus isolate was a BVDV 1 strain.

\section{Amplification, sequencing, and analysis of 5'UTR}

The fragment of 288 bp of 5'UTR gene was amplified from the isolated virus by RT-PCR. The amplified product was purified, cloned and sequenced. The sequence of the isolated BVDV1 strain was compared to the reference sequences using BLAST program. Result revealed that the isolated BVDV 1 strain was similar with the BVDV strains Singer, with sequence identity about 95\%. The sequence of 5'UTR has been deposited in GenBank with the accession No.JX878887.

\section{Phylogenetic analysis}

Phylogenetic analysis based on 5'UTR revealed the strain HN01 was closed to BVDV1a Singer (L32875). The homology for nucleotide of 5'UTR is $95.3 \%$, and with the strain SH1060 (JN248741) was 89.2\%. This result indicates that the newly isolated BVDV strain, HN01, belongs to subgroup BVDV 1a of genotype BVDV1 (Figure 2).

\section{Experimental infection}

Clinical signs were scored based on clinical severity, included depression, loss of appetite, nasal discharge, distress, excessive salivation, and elevated rectal temperatures. Two of the four BVDV infected calves developed significant clinical signs with nasal discharge and depression beginning at 2 days post-challenge (dpi), and subsequently 3 of four infected calves showed asthma and

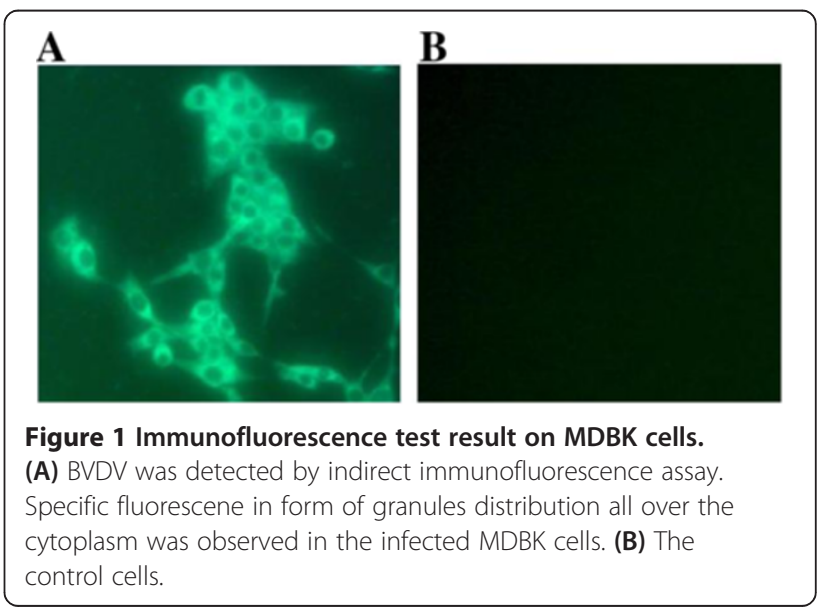




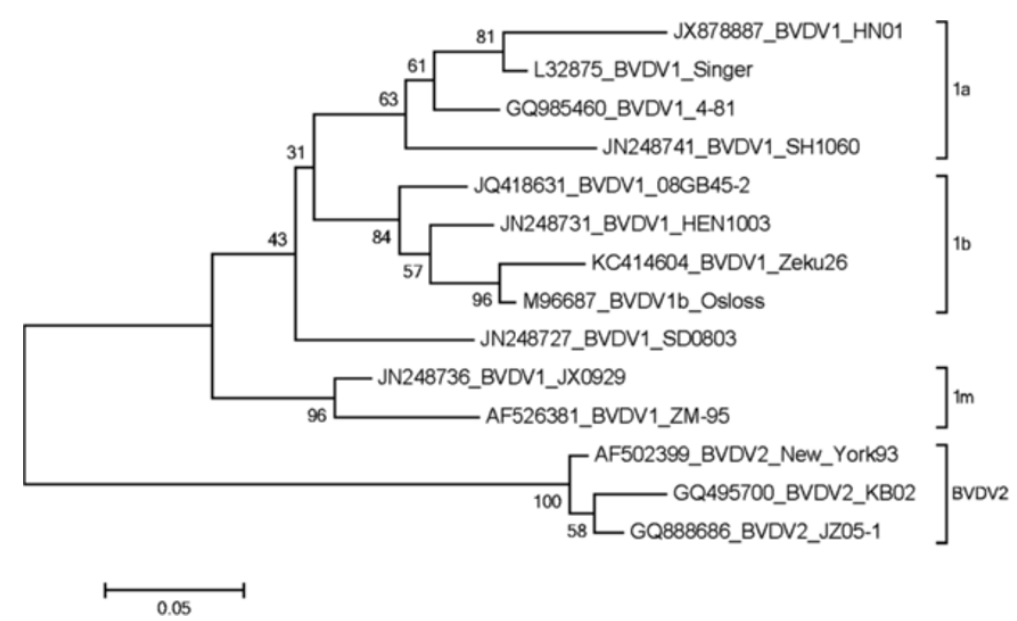

Figure 2 Phylogenetic tree analysis based the $\mathbf{5}^{\prime}$ UTR. The tree was created using the nucleotide sequences of the 13 BVDV strains retrieved from GenBank. The phylogenetic tree was prepared using the Neighbor-Joining method.

excessive salivation. Calves in the control group had no clinical signs during the experiment course. The rectal temperature of cattle \#655 was over $40^{\circ} \mathrm{C}$ from 6 dpi to 8 dpi with the highest temperature of $41.4^{\circ} \mathrm{C}$. The rectal temperature of cattle \#642 was over $40^{\circ} \mathrm{C}$ at 2,5 and $6 \mathrm{dpi}$ with the highest recorded temperature of $40.1^{\circ} \mathrm{C}$. The rectal temperature of animal $\# 675$ was over $40^{\circ} \mathrm{C}$ from 5 to $7 \mathrm{dpi}$ with the highest temperature of $41.1^{\circ} \mathrm{C}$. The rectal temperature of cattle \#666 was elevated to $40^{\circ} \mathrm{C}$ from 2 to 4 dpi with the higest temperature of $40.3^{\circ} \mathrm{C}$ (Figure 3A).

WBC counts of challenged calves started decreasing from day 2 post-challenge. The WBC counts of 655\# dropped significantly from $8.6\left(1000\right.$ per $\left.\mathrm{mm}^{3}\right)$ at day 0 to $3.6\left(1000\right.$ per $\left.\mathrm{mm}^{3}\right)$ at $4 \mathrm{dpi}$, a $58 \%$ reduction to the initial number. 642\# decreased from $7.2\left(1000\right.$ per $\left.\mathrm{mm}^{3}\right)$ (0 day) to 3.0 (1000 per $\mathrm{mm}^{3}$ ) (6 dpi), a $58 \%$ reduction to the initial number. The cattle of 675\# decreased from $10.3\left(1000\right.$ per $\left.\mathrm{mm}^{3}\right)$ (0 day) to $4.8\left(1000\right.$ per $\left.\mathrm{mm}^{3}\right)$ ( $2 \mathrm{dpi})$, a $53 \%$ reduction to the initial number. The cattle of $666 \#$ decreased from 10.1 (1000 per $\mathrm{mm}^{3}$ ) (0 day) to $4.6\left(1000\right.$ per $\left.\mathrm{mm}^{3}\right)(6 \mathrm{dpi})$, a $54.5 \%$ reduction to the initial number. Average greatest decline of WBC counts among the control animal group was less than 20\%, which were significantly less $(P<0.05)$ than those of the challenge group (Figure 3B).

Viral detection was positive from 2 dpi to $8 \mathrm{dpi}$ in nasal samples. Viral shedding was detected by virus isolating in MDBK cells from nasal swabs. Two infected cattle had viral shedding as early as $2 \mathrm{dpi}$. The long shedding period reached to 8 days after inoculation, and the highest shedding peak was reached at 4-8 dpi.

Two randomly chosen calves (\#675 and \#642) and one mock calf (\#799) were euthanized at 8 dpi for histopathology analysis. Gross pathological findings included hemorrhages in the spleen and mesenteric lymph nodes. Histopathologic changes included thymic and spleen atrophy, the lymph node was lymphadenopathy and hemorrhage, and lymphoid depletion of the Peyer's patches in all the infected calves (Figure 4). All of the samples from the control cattle did not show pathological changes.

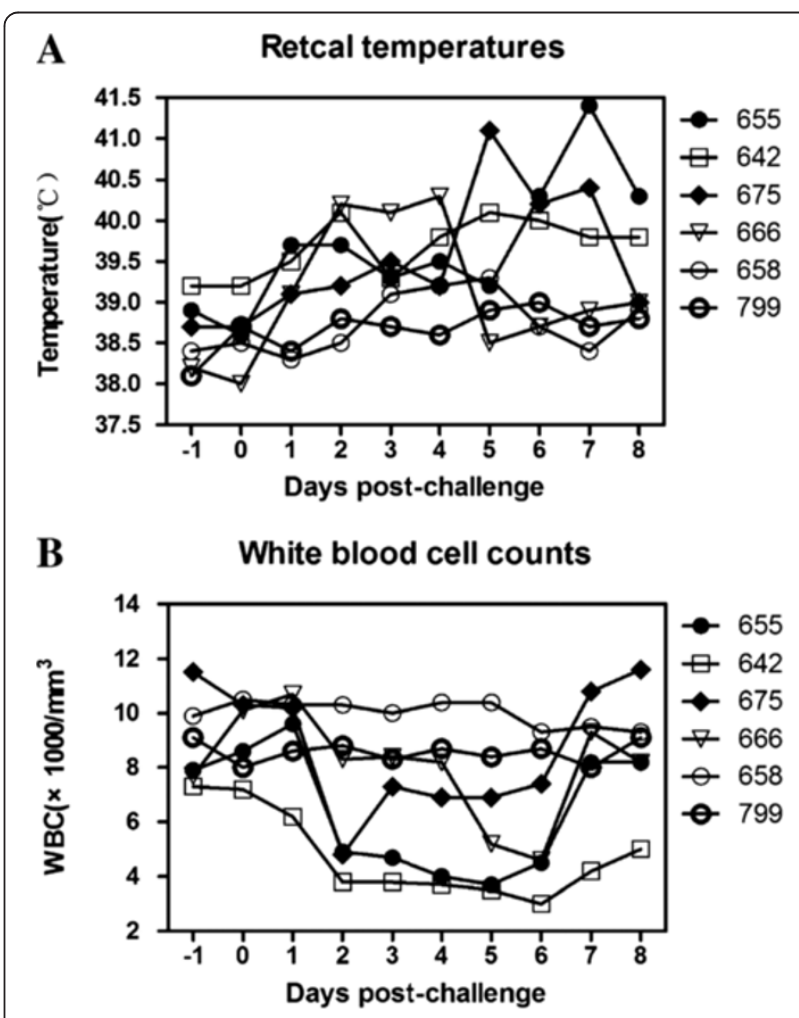

Figure 3 Experimental infection intranasal inoculating with the HN01 stain. (A) Elevated rectal temperatures. (B) Decrease of white blood cell counts. 


\section{Discussion}

This study was the first report on BVDV 1a isolated from cattle in China, and the pathogenesis of the isolate was tested by experimental infection. Similar virus at the genetic subtype was detected in pigs in China [43]. Identification of BVDV 1a in cattle and swine seemed that the virus have evolved well to replicate in different species. To our knowledge, the diversity of the genotype is a dominant character of the BVDV. Phylogenetic analysis is useful for molecular epidemiological studies and vaccine research.as well as tracing the origin of newly introduced viruses [19,44-46]. The 5'UTR analysis is commonly used to classify the genotypes of BVDV strains. To investigate the molecular feature of the strain, 13 reference sequences (Table 1) in China, USA and Korea field isolates were used to phylogenetic analysis. A high genetically identity with the BVDV1a strain was detected among all the reference sequences. Recently, a BVDV 1a strain named SH1060 was isolate from pigs in Shanghai, China [43], but the virus only has the $89.2 \%$ homology of 5'UTR with the HN01 reported in this study. This may suggest that the virus have the great variation in evolution between the different kind species.

The subgroup of BVDV might be correlated with the geographical origin [47]. Previous study indicated that the BVDV 1a subtype was predominant and widespread in neighboring countries, such as Korea and Japan [47,48]. In China and India, BVDV $1 \mathrm{~b}$ was the predominant subgenotypes $[27,49]$. Hence, the isolated BVDV1a strain in this study may be originated from the import of infected livestock. The findings of the current study also suggest a possible role of BVDV in the etiology of diarrhea and bovine respiratory disease. In addition, the presence of BVDV could represent a clinical threat to diary and cattle industry in China.

In this study, calves infected strain HN01 of BVDV1a showed the mild clinical signs, high rectal temperature and lymphopenia, which suggested that the strain had the moderate virulence to cattle. Previous studies on the

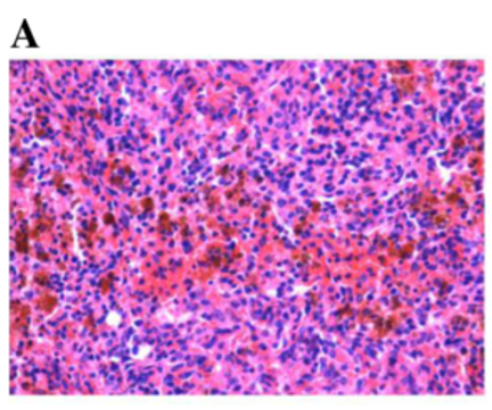

C

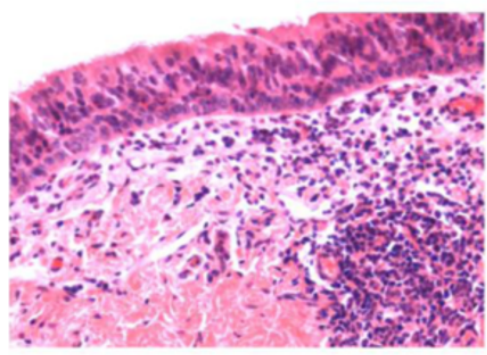

$\mathbf{E}$

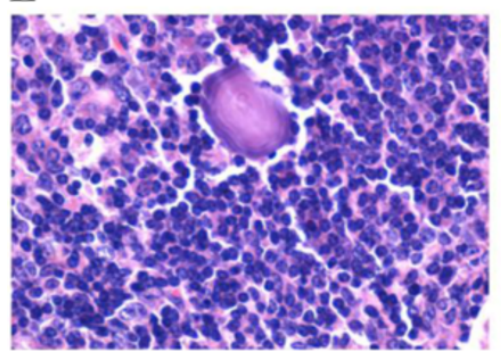

B

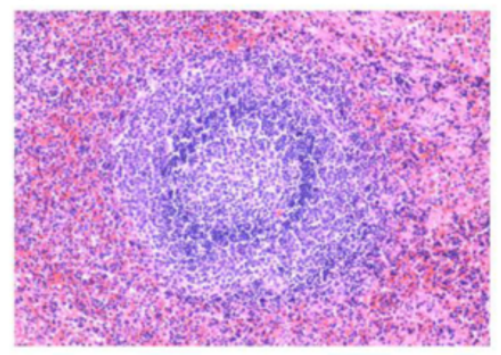

D

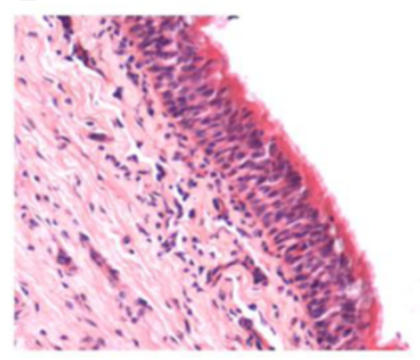

F

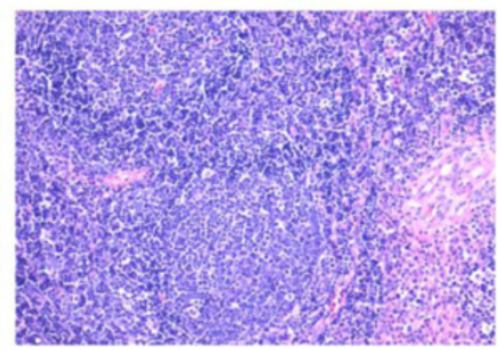

Figure 4 Histopathologic changes of spleen, trachea and mesenteric lymph nodes. (A) Red pulp of the spleen hemorrhage, hemosiderin macrophages increased significantly. (B) The control was normal. (C) Some mucosal epithelium of trachea swollen; neutrophil and plasma cells infiltrated in the lamina propria; lymphocytes proliferated; lymphocytic follicular increased. (D) The control was normal. (E) Macrophages and reticular cells proliferated and increased. (F) The control was normal. 
Table 1 Reference sequences from GenBank

\begin{tabular}{lccc}
\hline S. No & Isolate name & Accession number in GenBank & Country \\
\hline 1 & Singer & L32875 & USA \\
2 & Osloss & M96687 & USA \\
3 & New_York93 & AF502399 & USA \\
4 & HN01 & JX878887 & China \\
5 & ZM-95 & AF526381 & China \\
6 & JX0929 & JN248736 & China \\
7 & SD0803 & JN248727 & China \\
8 & HEN1003 & JN248731 & China \\
9 & Zeku26 & KC414604 & China \\
10 & JZ05-1 & GQ8886866 & China \\
11 & SH1060 & JN248741 & China \\
12 & KB02 & GQ495700 & Korea \\
13 & 08GB45-2 & JQ418631 & Korea \\
14 & $4-81$ & GQ985460 & Korea \\
\hline
\end{tabular}

pathogenesis of BVDV1 and BVDV2 demonstrated that the low virulent strains were characterized with a subclinical course, a mild short-term pyrexia, rectal temperatures between $39.2^{\circ} \mathrm{C}$ and $40.0^{\circ} \mathrm{C}$ for $1-2$ days, and a drop in circulating lymphocytes ranging between $20 \%$ and $40 \%$ [50]. In contrast, clinical signs infected with a high virulent strain were severe with a longer term and more severe pyrexia, temperatures above $40^{\circ} \mathrm{C}$, ranging upwards to $41.7^{\circ} \mathrm{C}$ for 3 or more days, decreases of greater than $40 \%$ in circulating lymphocytes and decreases of greater than $40 \%$ in platelets. Death losses ranging between $20 \%$ and $50 \%$ have been observed in field outbreaks associated with highly virulent BVDV2 strains [36,39,51]. Although the experimental animals showed over $40^{\circ} \mathrm{C}$ for 2 days, over $40 \%$ WBC drop, the virus was categorized as moderate virulence due to the lack of severe clinical signs. This study demonstrated that strain HN01 was an alternate challenge strain in addition to the currently available strain NY-1 for vaccine efficacy test from the USDA [39]. Furthermore, much of the research on BVDV virulence demonstrated that the clinical signs, such as depression, febrile response and excessive lacrimation were more reproducible than hemorrhage or diarrhea. It may be suggested that low virulence strains were more dominant in nature [52-54]. Despite the lack of severe clinical signs, infection with BVDV may transiently compromise the immune system and thus possibly predisposes cattle to secondary infections [52]. Measures such as vaccination should be taken to control BVDV1 infection.

\section{Conclusions}

In this study, a BVDV strain genotype 1a was firstly isolated from cattle herd in China. The study carried out a molecular epidemiology and pathogenesis on the strain. Calves inoculated with the isolate developed clinical signs, including high temperature, depression, cough and nasal discharge. The results confirmed the existence of the BVDV type 1a in China, and it may be helpful in preventing the BVD in China and a challenge virus strain for efficacy evaluations of vaccines.

\section{Materials and methods}

\section{Samples and virus isolation}

Twenty nasal swabs and blood samples were collected from the cattle that showed mild respiratory clinical signs, such as nasal discharge and cough in Henan province, China in 2010. The nasal swab samples were collected and put into a tube containing $2 \mathrm{ml}$ DMEM (HyClone, USA) supplemented with 10\% horse serum (Hyclone, USA), $150 \mu \mathrm{g} / \mathrm{ml}$ gentamicin sulfate (Sigma, USA), $7.5 \mu \mathrm{g} / \mathrm{ml}$ fungizone (Sigma, USA), and Streptomycin at $100 \mu \mathrm{g} / \mathrm{ml}$. Three milliliter $(3 \mathrm{ml})$ blood samples were collected using an EDTA vacuum blood tube from the jugular vein. All the samples were kept at $2-8^{\circ} \mathrm{C}$ and quickly transferred to the laboratory. Nasal swabs were inoculated into MDBK cell monolayers in 24-well tissue culture plates for virus isolation. Briefly, following centrifugation at $1500 \mathrm{rpm}$ for $10 \mathrm{~min}$, the samples were filtered through $0.45 \mu \mathrm{m}$ membrane (Sigma, USA) and then inoculated onto the MDBK cell monolayer cultured in $0.5 \mathrm{ml}$ DMEM (HyClone, USA) supplemented with $6 \%$ horse serum (Hyclone, USA) in 24-well cell culture plates, and incubated at $37^{\circ} \mathrm{C}$, with $5 \% \mathrm{CO}_{2}$ for 2 hours. Then, the supernatants were discarded, and plates were rinsed twice with PBS (pH7.2, $0.01 \mathrm{~mol} / \mathrm{L}$ ), and $1 \mathrm{ml}$ DMEM (HyClone, USA), with $3.5 \%$ horse serum was added. The infected-MDBK cell plates were checked daily and appearance of cytopathic effects (CPE) was observed and recorded. If the CPE was not found, the cultures were frozen and thawed twice and the clarified supernatant was passaged three times in MDBK cells. Un-infected MDBK cultures were included as negative controls and MDBK cells inoculated with BVDV NM01 strain, which was previously isolated and identified by our laboratory, was used as positive control. After 3-4 days of incubation at $37^{\circ} \mathrm{C}$, with $5 \%$ $\mathrm{CO}_{2}$ supply, the virus was confirmed by immunofluorescence on cell monolayers as described below.

\section{Virus neutralization test}

To identify the isolated virus, virus neutralization (VN) test was conducted using antisera raised in cattle against BVDV1a NM01, a vaccine strain in our laboratory. Briefly, virus fluids were mixed with the equal volume hyperimmune antisera (antibody VN titer $\geq 1: 64$ ) and incubated at $37^{\circ} \mathrm{C}$ for one hour, and then the mixture was transferred into MDBK cell cultures in the 96-well tissue 
culture plates. After 4 days of incubation at $37^{\circ} \mathrm{C}$, with $5 \% \mathrm{CO}_{2}$ supply, the plates were observed for CPE to determine if the virus isolate was neutralized by the BVDV antisera. The antisera positive control and negative control were also included in this test.

\section{Immunofluorescence assay}

To detect the BVDV in the infected-MDBK culture, an immunofluorescent assay (IFA) was conducted as follows. Briefly, cell lysate was added to each of four wells of a 96-well MDBK tissue culture plate. Positive virus (NM01 strain) and DMEM media (negative control) were also added to 4 wells respectively in the test. Then plates were incubated for 4 days at $37^{\circ} \mathrm{C}$, with $5 \% \mathrm{CO}_{2}$ supply. Then, the supernatants were dumped and plates were fixed with the mixture of $80 \%$ acetone and $20 \%$ methyl alcohol; the fixed plates were incubated with monoclonal antibody specific to anti-BVDV1 (E2/gp53 IgG2a Isotype, VMRD, USA). Finally, the rabbit antimouse fluorescein isothiocyanate (FITC)-conjugated immunoglobulin G (IgG) (Sigma, USA) was added to the plates, then incubated in a $37^{\circ} \mathrm{C}$ humid box for an hour. The plates were examined for fluorescence under a fluorescent microscope (Zeiss Axioskop-40, Germany).

\section{PCR amplification and sequencing}

Primers (Forward: 5'ATGCCCTTAGTAGGACTAGCA3'; Reverse: 5'TCAACTCCATGTGCCATGTAC3') for 5' UTR gene sequence of BVDV were designed according to the BVDV strain Singer (GenBank accession number L32875) and strain NADL (GenBank accession number M31182). Total BVDV RNA was extracted from infected MDBK cell fluids using Trizol reagent (Invitrogen, China) according to the manufacturer's instructions. The reverse transcription polymerase chain reaction (RT-PCR) was carried out using $5 \mu \mathrm{l}$ of RNA extraction samples and $1 \mu \mathrm{l}$ of BVDV reverse primer as reverse transcription primer in a $0.2 \mathrm{ml}$ tube for $5 \mathrm{~min}$ at $70^{\circ} \mathrm{C}$; and the tube was added with $1 \mu \mathrm{l}$ (200U) M-MLV reverse transcriptase RNase inhibitor and $2 \mu \mathrm{l}$ RNAse-free water, and then was incubated for one hour at $42^{\circ} \mathrm{C}$. The amplification of cDNA by PCR was carried out in a total volume of $50 \mu \mathrm{l}$ solution containing $1 \mu \mathrm{l} \mathrm{cDNA}, 5 \mu \mathrm{l} 10 \times$ Buffer, $3 \mu \mathrm{l} 2.5 \mathrm{mmol} / \mathrm{L}$ dNTP, $0.5 \mu \mathrm{l}$ each primer, $0.5 \mu$ l Platinum Pfx DNA polymerase and $39.5 \mu \mathrm{l}$ sterile water. Amplification was performed as follows: $95^{\circ} \mathrm{C}$ for $5 \mathrm{~min}$, and then submitted to 30 cycles of amplification. The conditions for the amplification were $1 \mathrm{~min}$ at $94^{\circ} \mathrm{C}, 1 \mathrm{~min}$ at $55^{\circ} \mathrm{C}$, and $1 \mathrm{~min}$ at $72^{\circ} \mathrm{C}$, then with a final extension at $72^{\circ} \mathrm{C}$ for $10 \mathrm{~min}$. The PCR products were detected by electrophoresis through a $1 \%$ agarose gel stained with ethydium bromide and visualized under UV light. The target fragment of PCR products were purified and cloned into pMD18-T vector (TaKaRa, Japan), and then transfected into E.coli DH5 $\alpha$ cells. The positive clones were selected for sequencing by Shanghai Invitrogen Biotechnology Co., Ltd.

\section{Sequences analysis}

The sequence analysis was performed by computer software DNASTAR (Madison, Wis USA) and MEGA5.1. The 5 'UTR gene sequence of the virus isolate was evaluated for further sub-genotype classification and compared to 13 BVDV reference sequences (Table 1) from NCBI database information to develop a phylogenetic tree. Percent identities and divergences were calculated using Neighbor-Joining method of Mega5.1 software.

\section{Experimentally infection Calves and housing}

Six 4-month old calves were obtained from a calf farm in Inner Mongolian, China. All animals were negative to BVDV and apparently healthy, presenting no signs of depression, cough or other health disorders. The selected animals were transported to an animal facility in Inner Mongolian. All animal experiments were approved by the Institutional Animal Care and Use Committee of Jilin University.

\section{Virus infection and temperature recording}

Three days prior to challenge, all animals were transferred to a bio-level 3 safety facility. Four calves were intranasally inoculated with $6 \mathrm{ml}$ of cell culture medium containing $10^{6.8} \mathrm{TCID}_{50}$ per milliliter of the HN01 strain, and other two calves were inoculated with the cell culture medium to serve as the controls. All the culture medium were demonstrated free of adventitious pathogens. The challenge procedure was performed by spraying $3 \mathrm{ml}$ of virus samples into each nostril, using an atomizer, and then the calves were monitored for 8 days. The temperature was taken two times at the same time every day by investigators who were unaware of the treatment codes in each study. Three randomly chosen calves were euthanized at 8 dpi for histopathology analysis.

\section{Clinical assessment}

Calves were clinically observed daily from 1 to 8 days post-challenge. Clinical signs including depression, cough, asthma, and other respiratory disease were recorded and scored using a scale of $0-3(0=$ absence; $1=$ mild; 2 = moderate; 3 = severe).

\section{Sample collection}

White blood cell (WBC) counts were conducted from 2 days pre-challenge through 8 days post-challenge and white blood cell (WBC) counts were conducted by a Vetscan HM5 veterinary hematology system (Abaxis, USA). Deep nasal swab specimens were collected at 1 day prior to challenge through 8 days post-challenge. After collection, swabs 
were placed into a tube containing $3 \mathrm{ml}$ of transport medium, consisting of DMEM (HyClone, USA) supplemented with $10 \%$ horse serum (Hyclone, USA), $150 \mu \mathrm{g} / \mathrm{ml}$ gentamicin sulfate (Sigma, USA), $7.5 \mu \mathrm{g} / \mathrm{ml}$ fungizone and streptomycin at $100 \mu \mathrm{g} / \mathrm{ml}$. The samples were kept at $2-8^{\circ} \mathrm{C}$ and quickly transferred to the laboratory. Upon arriving in laboratory, all swab specimens were stored at $-70^{\circ} \mathrm{C}$ or below until they were cultured for virus isolation.

\section{Histopathologic study}

On days $8 \mathrm{dpi}$, two calves in the infected group and one in the control group were euthanized; tissue samples of liver, spleen, lung, heart, kidney, intestine, mandibular lymph node, and mesenteric lymph node were collected and fixed in $10 \%$ buffered formalin for histopathologic analysis in Inner Mongolia agricultural university.

\section{Competing interests}

The authors declare that they have no competing interests.

\section{Authors' contributions}

WW participated in the design and conducted the majority of the experiments in the study and drafted the manuscript. XS and QT participated in the molecular genetic studies and the sequence alignment. YW and YJ took the animal experiment and collected samples. MX was performed the statistical analysis. WX and HW conceived of the study, and participated in its design. All authors read and approved the final manuscript.

\section{Acknowledgment}

I would like to express my gratitude to all the people who supported and assisted us in conducting this study. This work was performed under the auspices of the "Special Fund for Agro-scientific Research in the Public Interest project, No. 201003060" and we are thankful to SINOVET (BEIJING) BIOTHCHNOLOGY CO., LTD for providing the necessary facilities to carry out this work.

\section{Author details}

${ }^{1}$ Institute of Special Economic Animal and Plant Science, CAAS, No. 4899, Juye Street, 130122 Changchun, PR China. ${ }^{2}$ Sinovet (Beijing) Biotechnology Co., Ltd, No.5 Kaituo Street, Haidian District, 100085 Beijing, PR China. ${ }^{3}$ MSD Animal Health, No. 10 Jiuxianqiao Road, Chaoyang District, 100015 Beijing, PR China.

Received: 24 October 2013 Accepted: 17 January 2014

Published: 20 January 2014

\section{References}

1. Borsberry S: Challenges of BVDV eradication in 'closed' cattle herds. Vet Rec 2012, 170:652.

2. Czopowicz M, Kaba J, Schirrmeier H, Bagnicka E, Szalus-Jordanow O, Nowicki M, Witkowski L, Frymus T: Serological evidence for BVDV-1 infection in goats in Poland - short communication. Acta Vet Hung 2011, 59:399-404.

3. Pogranichniy RM, Schnur ME, Raizman EA, Murphy DA, Negron M, Thacker HL: Isolation and genetic analysis of bovine viral diarrhea virus from infected cattle in indiana. Vet Med Int 2011, 2011:925910.

4. Uttenthal A, Stadejek T, Nylin B: Genetic diversity of bovine viral diarrhoea viruses (BVDV) in Denmark during a 10-year eradication period. APMIS 2005, 113:536-541.

5. Canal CW, Strasser M, Hertig C, Masuda A, Peterhans E: Detection of antibodies to bovine viral diarrhoea virus (BVDV) and characterization of genomes of BVDV from Brazil. Vet Microbiol 1998, 63:85-97.

6. Wolfmeyer A, Wolf G, Beer M, Strube W, Hehnen HR, Schmeer N, Kaaden OR: Genomic (5'UTR) and serological differences among German BVDV field isolates. Arch Virol 1997, 142:2049-2057.
7. Siegwart N, Hilbe M, Hassig M, Braun U: Increased risk of BVDV infection of calves from pregnant dams on communal Alpine pastures in Switzerland. Vet J 2006, 172:386-388.

8. Otter A, Welchman Dde B, Sandvik T, Cranwell MP, Holliman A, Millar MF Scholes SF: Congenital tremor and hypomyelination associated with bovine viral diarrhoea virus in 23 British cattle herds. Vet Rec 2009 , 164:771-778.

9. Hessman BE, Sjeklocha DB, Fulton RW, Ridpath JF, Johnson BJ, McElroy DR: Acute bovine viral diarrhea associated with extensive mucosal lesions, high morbidity, and mortality in a commercial feedlot. J Vet Diagn Invest 2012, 24:397-404.

10. Yesilbag K, Gungor B: Seroprevalence of bovine respiratory viruses in North-Western Turkey. Trop Anim Health Prod 2008, 40:55-60.

11. Bielanski A, Loewen KS, Del Campo MR, Sirard MA, Willadsen S: Isolation of bovine herpesvirus-1 (BHV-1) and bovine viral diarrhea virus (BVDV) in association with the in vitro production of bovine embryos. Theriogenology 1993, 40:531-538.

12. Flores EF, Gil LH, Botton SA, Weiblen R, Ridpath JF, Kreutz LC, Pilati C, Driemeyer D, Moojen V, Wendelstein AC: Clinical, pathological and antigenic aspects of bovine viral diarrhea virus (BVDV) type 2 isolates identified in Brazil. Vet Microbiol 2000, 77:175-183.

13. Fulton RW, Ridpath JF, Saliki JT, Briggs RE, Confer AW, Burge LJ, Purdy CW, Loan RW, Duff GC, Payton ME: Bovine viral diarrhea virus (BVDV) $1 \mathrm{~b}$ : predominant BVDV subtype in calves with respiratory disease. Can J Vet Res 2002, 66:181-190.

14. Vilcek S, Durkovic B, Kolesarova M, Greiser-Wilke I, Paton D: Genetic diversity of international bovine viral diarrhoea virus (BVDV) isolates: identification of a new BVDV-1 genetic group. Vet Res 2004, 35:609-615.

15. Marques Antunes de Oliveira A, Stalder H, Peterhans E, Sauter KS, Schweizer M: Complete genome sequences of both biotypes of a virus pair of bovine viral diarrhea virus subgenotype 1k. Genome Announc 2013, 1.

16. Corapi WV, Donis RO, Dubovi EJ: Monoclonal antibody analyses of cytopathic and noncytopathic viruses from fatal bovine viral diarrhea virus infections. J Virol 1988, 62:2823-2827.

17. Harding MJ, Cao X, Shams H, Johnson AF, Vassilev VB, Gil LH, Wheeler DW, Haines D, Sibert GJ, Nelson LD, et al: Role of bovine viral diarrhea virus biotype in the establishment of fetal infections. Am J Vet Res 2002, 63:1455-1463.

18. Ridpath JF, Bolin SR: Differentiation of types $1 \mathrm{a}, 1 \mathrm{~b}$ and 2 bovine viral diarrhoea virus (BVDV) by PCR. Mol Cell Probes 1998, 12:101-106.

19. Flores EF, Ridpath JF, Weiblen R, Vogel FS, Gil LH: Phylogenetic analysis of Brazilian bovine viral diarrhea virus type 2 (BVDV-2) isolates: evidence for a subgenotype within BVDV-2. Virus Res 2002, 87:51-60.

20. Nagai M, Sato M, Nagano H, Pang H, Kong X, Murakami T, Ozawa T, Akashi H: Nucleotide sequence homology to bovine viral diarrhea virus 2 (BVDV 2) in the $5^{\prime}$ untranslated region of BVDVs from cattle with mucosal disease or persistent infection in Japan. Vet Microbiol 1998, 60:271-276.

21. Peletto S, Zuccon F, Pitti M, Gobbi E, Marco LD, Caramelli M, Masoero L, Acutis PL: Detection and phylogenetic analysis of an atypical pestivirus, strain IZSPLV_To. Res Vet Sci 2012, 92:147-150.

22. Gao Y, Wang S, Du R, Wang Q, Sun C, Wang N, Zhang P, Zhang L: Isolation and identification of a bovine viral diarrhea virus from sika deer in china. Virol J 2011, 8:83.

23. Li QC, Miao LG, Li HT, Liu YH, Zhang GL, Xiao JM: Genome sequencing and analysis of the bovine viral diarrhea virus-2 strain JZ05-1 isolated in China. Bing Du Xue Bao 2010, 26:238-243.

24. Vilcek S, Durkovic B, Kolesarova M, Paton DJ: Genetic diversity of BVDV: consequences for classification and molecular epidemiology. Prev Vet Med 2005, 72:31-35. discussion 215-219.

25. Bauermann FV, Flores EF, Ridpath JF: Antigenic relationships between Bovine viral diarrhea virus 1 and 2 and HoBi virus: possible impacts on diagnosis and control. J Vet Diagn Invest 2012, 24:253-261.

26. Zhu LQ, Ren $M$, Lin $Y Q$, Ding $X Y$, Zhang GP, Zhao X, Zhu GQ: Identification of a bovine viral diarrhea virus 2 isolated from cattle in China. Acta Virol 2009, 53:131-134.

27. Xue F, Zhu YM, Li J, Zhu LC, Ren XG, Feng JK, Shi HF, Gao YR: Genotyping of bovine viral diarrhea viruses from cattle in China between 2005 and 2008. Vet Microbiol 2010, 143:379-383.

28. Pellerin C, van den Hurk J, Lecomte J, Tussen P: Identification of a new group of bovine viral diarrhea virus strains associated with severe outbreaks and high mortalities. Virology 1994, 203:260-268. 
29. Nagai M, Ito T, Sugita S, Genno A, Takeuchi K, Ozawa T, Sakoda Y, Nishimori T, Takamura K, Akashi H: Genomic and serological diversity of bovine viral diarrhea virus in Japan. Arch Virol 2001, 146:685-696.

30. Minami F, Nagai M, Ito M, Matsuda T, Takai H, Jinkawa $Y$, Shimano T, Hayashi M, Seki Y, Sakoda Y, et al: Reactivity and prevalence of neutralizing antibodies against Japanese strains of bovine viral diarrhea virus subgenotypes. Comp Immunol Microbiol Infect Dis 2011, 34:35-39.

31. Shimazaki $T$, Sekiguchi $H$, Nakamura $S$, Taguchi $K$, Inoue $Y$, Satoh M: Segregation of bovine viral diarrhea virus isolated in Japan into genotypes. J Vet Med Sci 1998, 60:579-583.

32. Vilcek S, Mojzisova J, Bajova V, Paulik S, Strojny L, Durkovic B, Hipikova V: A survey for BVDV antibodies in cattle farms in Slovakia and genetic typing of BVDV isolates from imported animals. Acta Vet Hung 2003, 51:229-236.

33. Pizarro-Lucero J, Celedon MO, Aguilera M, de Calisto A: Molecular characterization of pestiviruses isolated from bovines in Chile. Vet Microbiol 2006, 115:208-217.

34. Yilmaz H, Altan E, Ridpath J, Turan N: Genetic diversity and frequency of bovine viral diarrhea virus (BVDV) detected in cattle in Turkey. Comp Immunol Microbiol Infect Dis 2012, 35:411-416.

35. Giammarioli M, Pellegrini C, Casciari C, Rossi E, De Mia GM: Genetic diversity of bovine viral diarrhea virus 1: Italian isolates clustered in at least seven subgenotypes. J Vet Diagn Invest 2008, 20:783-788.

36. Liebler-Tenorio EM, Ridpath JE, Neill JD: Distribution of viral antigen and development of lesions after experimental infection with highly virulent bovine viral diarrhea virus type 2 in calves. Am J Vet Res 2002, 63:1575-1584

37. Carman S, van Dreumel T, Ridpath J, Hazlett M, Alves D, Dubovi E, Tremblay R, Bolin S, Godkin A, Anderson N: Severe acute bovine viral diarrhea in Ontario, 1993-1995. J Vet Diagn Invest 1998, 10:27-35

38. Odeon AC, Kelling CL, Marshall DJ, Estela ES, Dubovi EJ, Donis RO: Experimental infection of calves with bovine viral diarrhea virus genotype II (NY-93). J Vet Diagn Invest 1999, 11:221-228.

39. Ridpath JF, Neill JD, Peterhans E: Impact of variation in acute virulence of BVDV1 strains on design of better vaccine efficacy challenge models. Vaccine 2007, 25:8058-8066.

40. Zhu LQ, Lin YQ, Ding XY, Ren M, Tao J, Wang JY, Zhang GP, Zhu GQ: Genomic sequencing and characterization of a Chinese isolate of Bovine viral diarrhea virus 2. Acta Virol 2009, 53:197-202.

41. Zhong F, Li N, Huang X, Guo Y, Chen H, Wang X, Shi C, Zhang X: Genetic typing and epidemiologic observation of bovine viral diarrhea virus in Western China. Virus Genes 2011, 42:204-207.

42. Gao S, Du J, Shao J, Lang Y, Lin T, Cong G, Zhao F, Belak S, Liu L, Chang H, Yin H: Genome analysis reveals a novel genetically divergent subgenotype of bovine viral diarrhea virus in China. Infect Genet Evol 2013.

43. Deng Y, Sun CQ, Cao SJ, Lin T, Yuan SS, Zhang HB, Zhai SL, Huang L, Shan $T L$, Zheng $H$, et al: High prevalence of bovine viral diarrhea virus 1 in Chinese swine herds. Vet Microbiol 2012, 159:490-493.

44. Nagai M, Hayashi M, Itou M, Fukutomi T, Akashi H, Kida H, Sakoda Y: Identification of new genetic subtypes of bovine viral diarrhea virus genotype 1 isolated in Japan. Virus Genes 2008, 36:135-139.

45. Behera SP, Mishra N, Vilcek S, Rajukumar K, Nema RK, Prakash A, Kalaiyarasu S, Dubey SC: Genetic and antigenic characterization of bovine viral diarrhoea virus type 2 isolated from cattle in India. Comp Immunol Microbiol Infect Dis 2011, 34:189-196.

46. Mishra N, Dubey R, Rajukumar K, Tosh C, Tiwari A, Pitale SS, Pradhan HK: Genetic and antigenic characterization of bovine viral diarrhea virus type 2 isolated from Indian goats (Capra hircus). Vet Microbiol 2007, 124:340-347.

47. Yamamoto T, Kozasa T, Aoki H, Sekiguchi H, Morino S, Nakamura S: Genomic analyses of bovine viral diarrhea viruses isolated from cattle imported into Japan between 1991 and 2005. Vet Microbio/ 2008, 127:386-391.

48. Oem JK, Hyun BH, Cha SH, Lee KK, Kim SH, Kim HR, Park CK, Joo YS: Phylogenetic analysis and characterization of Korean bovine viral diarrhea viruses. Vet Microbiol 2009, 139:356-360.

49. Mishra N, Vilcek S, Jain P, Pitale SS, Pradhan HK: Genetic analysis of Indian bovine viral diarrhea virus 1 isolates in $N(p r o)$ and entire gene region coding structural proteins. Acta Virol 2006, 50:39-44.
50. Liebler-Tenorio EM, Greiser-Wilke I, Pohlenz JF: Organ and tissue distribution of the antigen of the cytopathogenic bovine virus diarrhea virus in the early and advanced phase of experimental mucosal disease. Arch Virol 1997, 142:1613-1634.

51. Liebler-Tenorio EM, Ridpath JF, Neill JD: Lesions and tissue distribution of viral antigen in severe acute versus subclinical acute infection with BVDV2. Biologicals 2003, 31:119-122.

52. Liebler-Tenorio EM, Ridpath JF, Neill JD: Distribution of viral antigen and development of lesions after experimental infection of calves with a BVDV 2 strain of low virulence. J Vet Diagn Invest 2003, 15:221-232.

53. Hamers C, Couvreur B, Dehan P, Letellier C, Lewalle P, Pastoret PP, Kerkhofs P: Differences in experimental virulence of bovine viral diarrhoea viral strains isolated from haemorrhagic syndromes. Vet J 2000, 160:250-258.

54. Castrucci G, Osburn BI, Ferrari M, Traldi V: An experimental contribution to the study of the pathogenesis of bovine viral diarrhea virus infection. Comp Immunol Microbiol Infect Dis 1992, 15:163-169.

doi:10.1186/1743-422X-11-8

Cite this article as: Wang et al: A bovine viral diarrhea virus type 1a strain in China: isolation, identification, and experimental infection in calves. Virology Journal 2014 11:8.

\section{Submit your next manuscript to BioMed Central and take full advantage of:}

- Convenient online submission

- Thorough peer review

- No space constraints or color figure charges

- Immediate publication on acceptance

- Inclusion in PubMed, CAS, Scopus and Google Scholar

- Research which is freely available for redistribution 